\title{
Merto
}

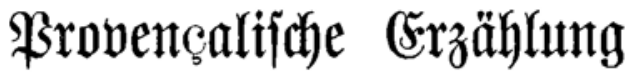

bort

\section{Frederi Miítral.}

\author{
Deutiad) \\ bon \\ $\mathfrak{A} \mathfrak{u g} \mathfrak{u} \mathfrak{f t} \mathfrak{B} \operatorname{ertud}$.
}

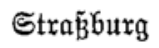

Berlag von Rarl J. Trübner.

1891. 
